\title{
A sedimentation study to optimize the dispersion of alumina nanoparticles in water
}

\section{(Um estudo de sedimentação para otimizar a dispersão de nanopartículas de alumina em água)}

\author{
S. Manjula ${ }^{1}$, S. Mahesh Kumar' ${ }^{2}$ A. M. Raichur ${ }^{3}$, G. M. Madhu ${ }^{1}$, R. Suresh ${ }^{1}$,M. A. Lourdu Anthony Raj ${ }^{* 1}$ \\ ${ }^{I}$ Department of Chemical Engineering, R. V. College of Engineering, Bangalore 560 059, India \\ ${ }^{2}$ Ceramic Technological Institute, EPD/CBU/BHEL, Bangalore 560 012, India \\ ${ }^{3}$ Department of Metallurgy, I. I. Sc., Bangalore - 560 012, India
}

\begin{abstract}
Sedimentation studies have been carried out to optimize the dispersion conditions of aqueous alumina nanopowder suspensions with or without dispersants (ammonium salt of polymethacrylic acid or rhamnolipids at 15\%). Different dispersant dosages, solid loadings, pulp densities and $\mathrm{pH}$ values were examined. The iso-electric point (IEP) of the alumina nanopowder was found to be $\mathrm{pH}_{\mathrm{iep}}=9.2$. The experiments revealed that the polymethacrylic acid was more effective as dispersant than rhamnolipids in a wide range of $\mathrm{pH}$ at all solidloading conditions tested. Optimum dispersant dosages for polymethacrylic acid and rhamnolipids to achieve maximum stability of alumina nanodispersion at iso-electric point were found to be $9.25 \mathrm{mg} / \mathrm{g}$ and $57.75 \mathrm{mg} / \mathrm{g}$ solids, respectively.
\end{abstract}

Keywords: alumina nanoparticles, sedimentation, iso-electric point, bio-surfactant JBR215, darvan C.

\section{Resumo}

Foram feitos estudos de sedimentação para otimizar as condições de dispersão de suspensões aquosas de pós de alumina nanométrica com e sem dispersantes (sais de amônia de ácido poliacrílico ou rhamnolipídeos a 15\%). Foram examinados diferentes dosagens de dispersante, cargas de sólidos, densidades de pasta e valores de $\mathrm{pH}$. O ponto isoelétrico do pó de alumina nanométrica obtido foi $\mathrm{pH}_{\text {iep }}=9,2$. Os experimentos mostraram que numa ampla faixa de pH e para todas as condições de carga de sólidos testadas, o ácido polimetacrílico foi mais efetivo como dispersante que o rhamnolipídeo. Os teores otimizados de dispersante para que as dispersões de alumina nanométrica atinjam estabilidade máxima, obtidos para o ácido polimetacrílico e para o rhamnolipídeo foram, respectivamente, 9,25 mg/g e 57,75 mg/g de sólidos.

Palavras-chave: nanopartícula de alumina, sedimentação, ponto isoélétrico, bio-surfactante JBR215, darvan C.

\section{INTRODUCTION}

The development of nanomaterials and ultra-thin functional coatings of nanoparticles will play an important role in many products in the future, such as membranes, super-hard materials and super-fast computers, dirt-repellent surfaces, new cancer treatments, scratch-proof coatings and eco friendly fuel cells with highly effective electro-catalysts. The products manufactured by nanotechnology have already registered double-digit growth rates with an estimated cost of hundreds of billions US\$ till 2002 [1]. Nanoparticles have become the core of this technology. The preparation of stable and uniform powder suspensions is crucial in determining the quality of nanocoatings.

A suspension is a dispersion of solid particles in a liquid. A colloidal suspension is a sol having significant properties when the size of the particles is of the order of few nanometers or less. In the suspension of large particles, for example,

* Corresponding Author. Fax : +91-080-28600337.

E-mail: antony mal@yahoo.com

2- Author present address: Dept. of Biotechnology,

R.V.College of Engineering, Bangalore-560059, India.
$10 \mu \mathrm{m}$ or larger, hydrodynamic interactions dominate the suspension flow properties and particle packing behavior. In colloidal suspensions, interaction forces between particles as well as hydrodynamic interactions play a vital role in determining the flow and particle packing properties.

Solid dispersion is the vehicle in dip-coating, in flirtation coating mode, there is a transition from low to high solid volume faction near the particle phase boundary. In this process, the flow behavior of the suspension and that of the particulate flow units become important. In film-coating mode, the flow behavior of the suspension is more important. Drying process is associated with changes in the properties of suspension, which in turn affects the final microstructure of the coating obtained. A homogeneous particle packing in the coating can be obtained when the suspension flow units do not change with time during the coating process. In industrial practice, it is often desirable that the suspension properties are stable for a long period (shelf life) due to economic reasons. This means that sedimentation and ageing should not be allowed and must be prevented.

In particular, the formation of metal oxide suspensions in the presence of electrolytes can be described according to the 
DLVO theory $[2,3]$. The degree of aggregation of metal oxide particles is determined by the height of the potential barrier (zeta-potential), which results from an electrical double layer at the individual particles. This double layer is produced by acid-base reaction (peptization) at the particle/water interface due to the amphoteric nature of the metal oxide surfaces. This way, the strength of the repulsion forces essentially depends on the $\mathrm{pH}$, as well as on nature and concentration of the electrolyte. The inter-particle interaction energy in presence of additives, surface-active agents (dibasic ammonium citrate - DAC, polymethacrylic acid, albumin or lignosulfonates), in the suspension has been well presented by a number of authors [4-9]. In the present study, the effect of dispersant, solid concentration, pulp density, and $\mathrm{pH}$ has been investigated on the suspension of nano-size alumina particles in water.

\section{MATERIALS AND METHODS}

High purity alumina (99.6\%) obtained from Sasol North America Inc. (Tucson, Arizona, USA) was used. The average particle size of alumina was $380 \mathrm{~nm}$. A scanning electron microscopy (SEM) image of the sample is shown in Fig. 1.

To establish a comparative study, two types of dispersants were used. The first one consisted of ammonium salt of polymethacrylic acid, (R.T. Vanderdilt Co. Norwalk, CT, USA) and was commercially available with the trade name Darvan C (25\% aqueous solution) and has a molecular weight of about $13000 \mathrm{~g} / \mathrm{mol}$. The other one was bio-
Table I - Characteristic properties of Darvan C. [Tabela I - Propriedades características do Darvan C.]

\begin{tabular}{cc}
\hline Property & Typical values/Nature \\
\hline Molecular weight $(\mathrm{g} / \mathrm{mol})$ & 13000 (approx) \\
Active matter $(\mathrm{wt} \%)$ & 35 \\
Density $(\mathrm{g} / \mathrm{cc})$ & 1.11 \\
$\mathrm{pH}$ & 7.5 \\
Ionic nature & Anionic \\
\hline
\end{tabular}

surfactant JBR215 (Jeneil Biosurfactant Co. LLC, Saukville, WI). It is an aqueous solution of rhamnolipids at $15 \%$ concentration. It is obtained from sterilized and centrifuged fermentation broth in which most proteins are removed. Two major rhamnolipids, RLL (R1) and RRLL (R2) are present. Chemically, rhamnolipids are glycosides of rhamnose (6deoxymannose) and beta-hydroxydecanoic acid. It is dark reddish-brown solution with soapy odour. Characteristic properties of Darvan C and JBR215 bio-surfactant are listed in Tables I and II, respectively.

Double distilled water was used for all experiments. All other reagents used in the experiments were of analytical grade (AR) (S. D. Fine Chem. India Ltd.).The $\mathrm{pH}$ of the dispersion was adjusted using $0.1 \mathrm{~N}$ solution of $\mathrm{HCl}$ and $\mathrm{KOH}$.

Sedimentation tests were carried out under various conditions to determine the iso-electric $\mathrm{pH}$, optimum dosage of dispersants, and effect of pulp density on the stability of dispersion.



Figure 1: SEM image of the alumina sample used in the experiments.

[Figura 1: Imagem da amostra de alumina utilizada nos experimentos, obtida por microscopia eletrônica de varredura (MEV).] 
Table II - Typical characteristics of bio-surfactant JBR215. [Tabela II - Características típicas do bio-surfactante JBR215.]

\begin{tabular}{cc}
\hline Property & Typical values/Nature \\
\hline Specific Gravity & $1.12-1.14$ \\
$\mathrm{pH}$ & $6.5-7.5$ \\
Appearance & Dark brown viscous suspension \\
Odor & Mild cooked odor \\
Solubility in Water & Soluble at neutral pH \\
Suitable Diluents & Water, most common alcohols \\
Suggested & Active Rhamnolipid \\
Starting & Ingredient: $1.0,0.1,0.01 \%$ \\
Concentrations & \\
\hline
\end{tabular}


Figure 2: Structural formula of a) RLL (R1) b) RRLL (R2).

[Figura 2: Fórmula estrutural do a) RLL (R1), b) RRL (R2).]

A pre-established solid content was dispersed in $100 \mathrm{~mL}$ distilled water. Suspension was thoroughly stirred for 10 $\mathrm{min}$, and transferred to $100 \mathrm{~mL}$ measuring jar, where it was allowed to stand undisturbed for 20 to $24 \mathrm{~h}$. Drop in the solidliquid interface height was noted at regular intervals of time.

For the determination of iso-electric $\mathrm{pH}, 8$ different measuring jars, each containing $3 \mathrm{~g}$ of alumina $\left(\mathrm{Al}_{2} \mathrm{O}_{3}\right)$ powder dispersed in $100 \mathrm{~mL}$-distilled water, were set for observation. A pH dispersion gradient ranging from 3 to 10 was established in the set of jars. A blank sedimentation rate without any dispersant was also investigated.

To optimize the dosage of dispersant, $3 \mathrm{~g}$ of alumina powder dispersed in $100 \mathrm{~mL}$ distilled water was freshly prepared in 6 different measuring jars. The iso-electric $\mathrm{pH}$, determined as previously described, was maintained. Different volumes of dispersant were added to each jar. Drop in height of interface as a function of time was recorded for Darvan C and Bio-Surfactant.

The effect of $\mathrm{pH}$ on the dispersion with optimum dosage of dispersant was studied by conducting similar settling tests. In this case, the solid concentration and dispersant dosage were maintained constant for a range of $\mathrm{pH}$ from 3 to 10 .

To study the effect of variation in pulp-density on dispersion stability, settling tests were carried out at different amounts of solid. Dispersions were prepared and maintained at iso-electric $\mathrm{pH}$. The amount of dispersant added was proportional to the weight $\%$ of solid in the dispersion. The proportionality constant have been determined by the optimum dosage tests.

\section{RESULTS AND DISCUSSION}

\section{Effect of pH}

Variations in the quality of the dispersion of alumina in water at $\mathrm{pH}$ ranging from 3.3 to 10.12 in the absence of any dispersant are shown in Figs. 3 and 4. The drop in dispersion volume of the interface is plotted as a function of time at various $\mathrm{pH}$ values of the dispersion. The amount of solid maintained in each case was $3 \mathrm{wt} \%$. The dispersion was highly stable at lower $\mathrm{pH}$ (from 3.3 to 7.1 ) and the instability was set between the $\mathrm{pH}$ range of 9.2 to 9.6 . The rate of settling was maximum at $\mathrm{pH}$ 9.6. At this $\mathrm{pH}$, a very clear supernatant and a sharp interface were observed. At $\mathrm{pH}$ greater than 10 , the rate of settling was observed to be extremely low. But it has to be noted that a significant quantity of solid particles settled very rapidly, leaving behind the remaining solid particles suspended in water. As a result, a stable suspension with some amount of settled solid particles was obtained. The stability of dispersion in the lower $\mathrm{pH}$ range could be due to the high positive surface charge in acidic environment. Since alumina is a basic oxide, it consumes $\mathrm{H}^{+}$ions, resulting in increased $\mathrm{pH}$, and acquires positive charges at the solution interface. The suspensions, even without any dispersant, dispersed well because of their positive surface charge. On the other hand, in $\mathrm{pH}$ range from 9.2 to 9.6 , there is a very sharp drop in dispersion volume as the surface approaches the point of no charge. Further, as the $\mathrm{pH}$ was raised the dispersion got stabilized. This could be due to negative surface charge on the alumina particles in basic environment. The stability, however, was not significant at higher acidity. This can be 


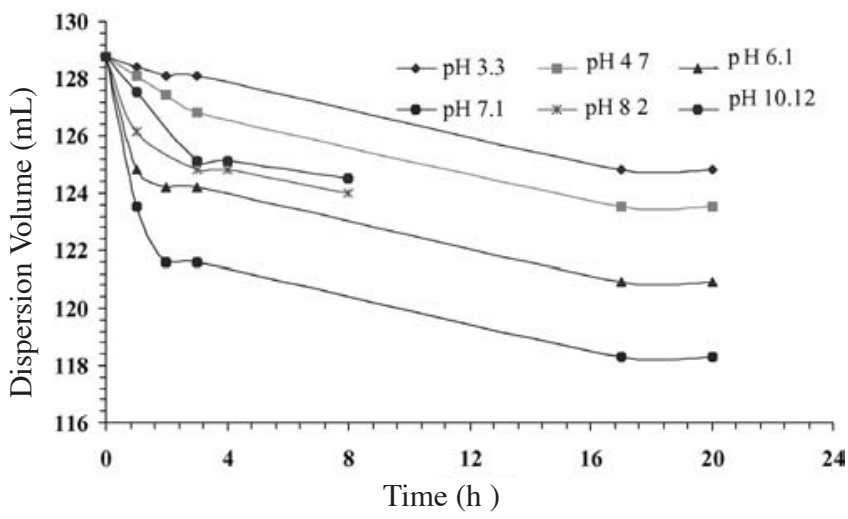

Figure 3: Settling rate of alumina nanoparticles in the absence of additives.

[Figura 3: Taxa de sedimentação da alumina nanométrica na ausência de aditivos.]

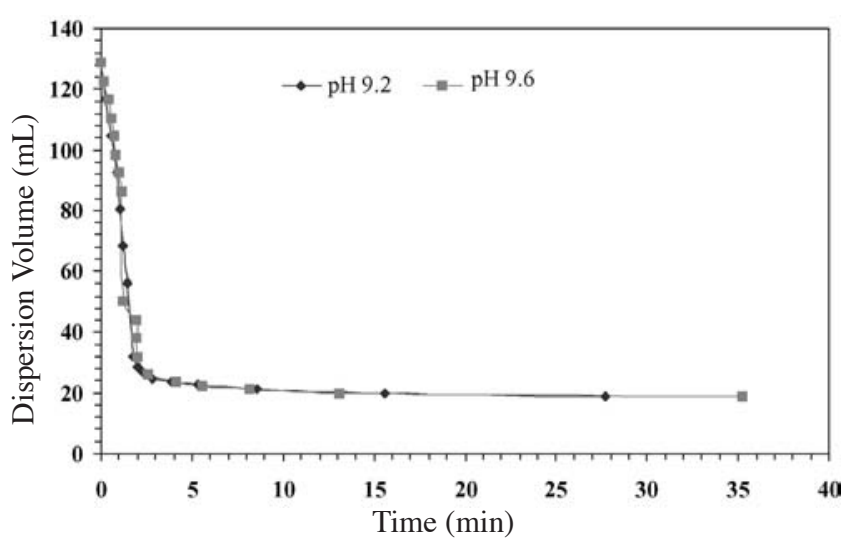

Figure 4: Settling rate of alumina nanoparticles in the absence of additives.

[Figura 4: Taxa de sedimentação da alumina nanométrica na ausência de aditivos.]

explained on the basis of the fact that the surface charge is not altered beyond the point of null charge. The IEP of alumina was found to be around $\mathrm{pH} 9.2$, which is in agreement with values reported elsewhere $[5,8,10]$. The charge on the particles near IEP is either minimal or zero. Therefore, all particles have natural tendency to agglomerate and settle very rapidly. In high alkaline $\mathrm{pHs,}$ the charge on alumina particles was slightly negative and hence, the dispersion volume was found to be less.

The variation of the dispersion volume as a function of $\mathrm{pH}$ is shown in Fig. 5. The graph is drawn from selecting the values obtained at $3 \mathrm{~h}$ line from Fig. 3 and Fig. 4. A sharp drop is seen at $\mathrm{pH} \mathrm{9,} \mathrm{which} \mathrm{clearly} \mathrm{shows} \mathrm{that} \mathrm{the} \mathrm{point} \mathrm{of}$ null charge was reached and the corresponding $\mathrm{pH}$ value can be read directly from this plot. Hence, this plot can be directly used to set the $\mathrm{pH}$ condition for safe application of the dispersion without dispersant. In this particular case, the highly acidic $\mathrm{pH}$ range was the safest condition for obtaining a stable dispersion.

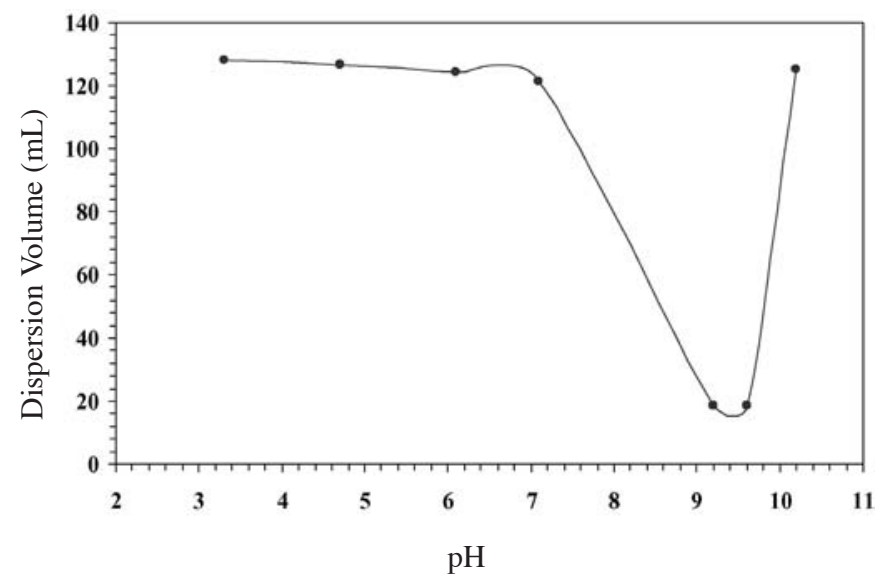

Figure 5: Result of Sedimentation tests for alumina nanodispersion at different $\mathrm{pHs}$.

[Figura 5: Resultado dos testes de sedimentação para a nanodispersão da alumina em diferentes $\mathrm{pHs}$.]

\section{Effect of dispersant}

\section{Polymethacrylic Acid-Darvan C}

With the addition of a suitable dispersant to the dispersion, the situation was completely changed. Variation in the dispersion volume as a function of time with different amounts of polyelectrolyte dispersant, Darvan C, added to the dispersion, is shown in Fig. 6. The $\mathrm{pH}$ maintained for this set of experiments was 9.2, which correspond to the IEP. At IEP, the dispersion was highly unstable and required an additive to induce stability. A milky dispersion with high degree of stability was obtained even with few micro liters of Darvan C added to $100 \mathrm{~mL}$ of dispersion. Higher volumes of dispersant enhanced the stability only to certain extent. The stability of dispersion, even at IEP of alumina, could be due to the fact that alumina particles are highly negatively charged in presence of Darvan C. This, in turn, is due to dissociation of Darvan C, which induced electrostatic repulsion among like charged particles resulting in better dispersion. Fig. 7 gives the variation in the liquid-solid interface height as a function of concentration of Darvan C.

At regular time intervals the observation was made up to $21 \mathrm{~h}$. No appreciable changes were observed in the first few hours. The increasing amount of Darvan $\mathrm{C}$ the rendered stability of particle dispersion interface (saturation value). Beyond saturation point, increasing the concentration of the dispersant had no effect on stability. Hence, the point where the plateau was reached can be taken as the optimum dosage of dispersant.

The poly-electrolytic dispersant is known to dissociate in aqueous environment prior to being absorbed onto the surface of solid particles. Steric repulsion takes place between particles and the dispersion stabilizes. Higher the amount of dispersant, greater the adsorption. Beyond 


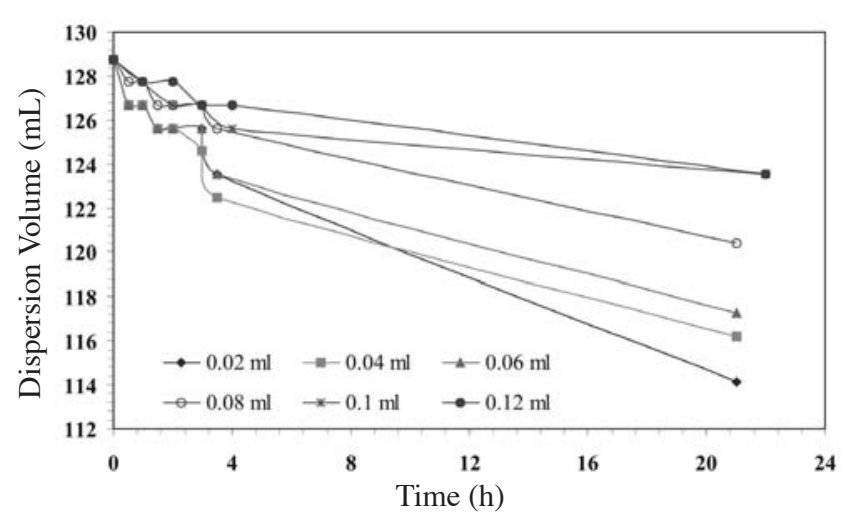

Figure 6: Settling rate of alumina nanoparticles in the presence of Darvan $\mathrm{C}$ in different concentrations.

[Figura 6: Taxa de sedimentação da alumina nanométrica ne presença de diferentes teores de Darvan C.]

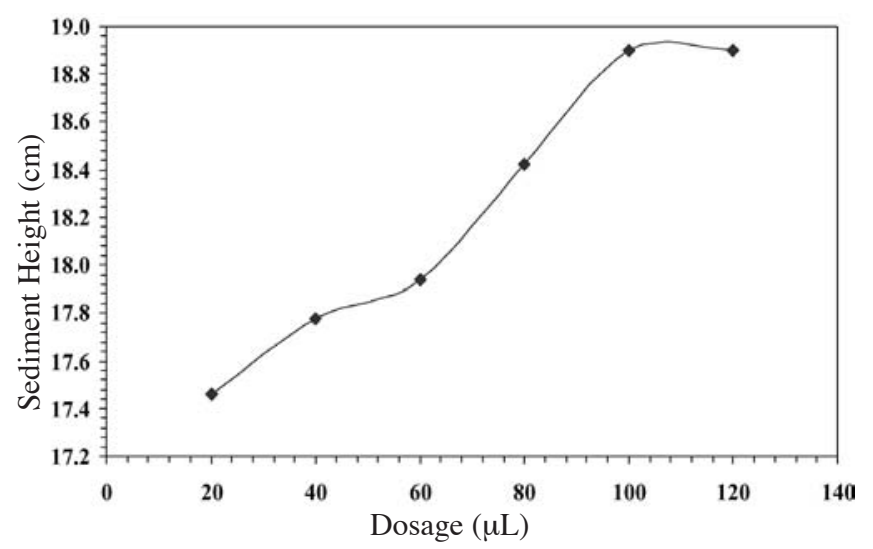

Figure 7: Variation of interface height in aqueous dispersion of alumina nanoparticles for different concentrations of Darvan C.

[Figura 7: Variação da altura da interface em dispersões aquosas de alumina nanométrica para diferentes teores de Darvan C.]

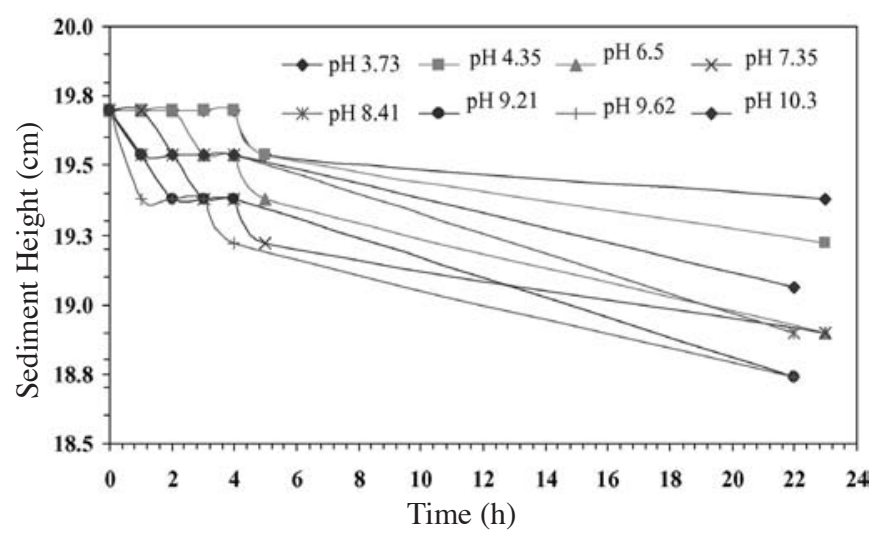

Figure 8: Settling rate of alumina nanoparticles with optimum dosage of Darvan $\mathrm{C}$ at different $\mathrm{pHs}$.

[Figura 8: Taxa de sedimentação da alumina nanométrica em diferentes $\mathrm{pHs}$, para teor otimizado de Darvan C.] the point of optimum dosage, the surface saturates with dispersant molecules, resulting in no further increase in the dispersion volume beyond this point.

In aqueous medium, Darvan $\mathrm{C}$ has proved to be one of the best dispersants for alumina [8]. Its performance in a $\mathrm{pH}$ range 3.73 to 10.3 is shown in Fig. 8. Darvan C exhibited good stabilizing action in both acidic and alkaline environments.

\section{JBR 215 Bio-Surfactant}

The settling rate of alumina nanodispersions at different concentrations of JBR215 bio-surfactant is shown in Fig. 9. The amount of dispersant used in this case was considerably high, compared to Darvan C. But, the stability achieved was on par with that of Darvan C. A light brown tinge was observed due to the coloring matter present in the natural dispersant. Though the dispersion volume was high for the range of concentrations studied, some amount of solid settling was observed from the dispersions with relatively small amounts of dispersant dosage. Due to the soapy nature of the dispersant, foaming was observed during stirring.

Mechanism of stabilizing action of bio-surfactant was not attempted here. But, it can be clearly inferred from the sedimentation tests, that the bio-surfactant stabilizes the dispersion to a very large extent. The plot of interface height as a function of the dosage of bio-surfactant is shown in Fig. 10 , which indicates that minimum amount of dispersant is required to achieve a stable dispersion. The optimum dosage was read at the point where the line begins to flatten. Beyond the point of optimum dosage, increase in the concentration of dispersant had no significant effect on the stability of the dispersion.

The variation of interface height with time of alumina nanodispersions with optimum dose of JBR215, prepared at various $\mathrm{pH}$ values, is shown in Fig. 11. It can be concluded that the performance of the bio-surfactant was better in alkaline medium. Poor performance in acidic medium could

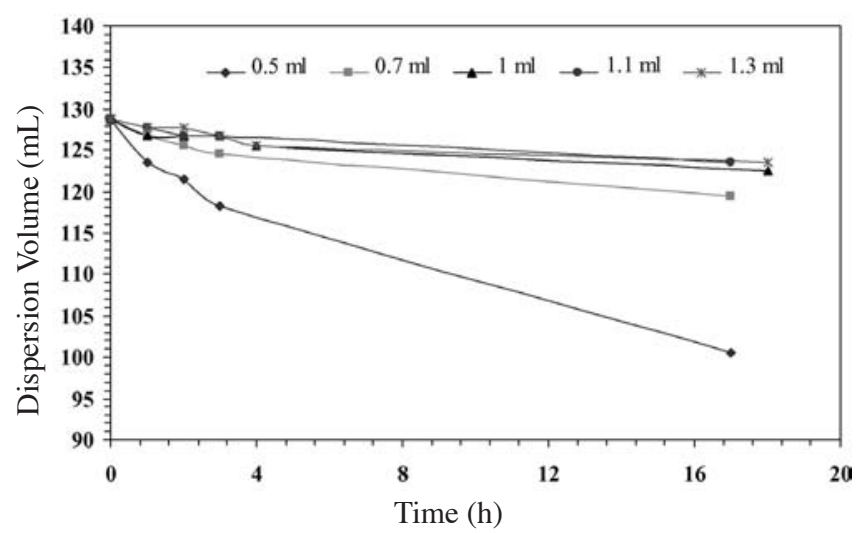

Figure 9: Settling rate of alumina nanoparticles with JBR215 at different concentrations.

[Figura 9: Taxa de sedimentação da alumina nanométrica para diferentes teores de JBR215.] 


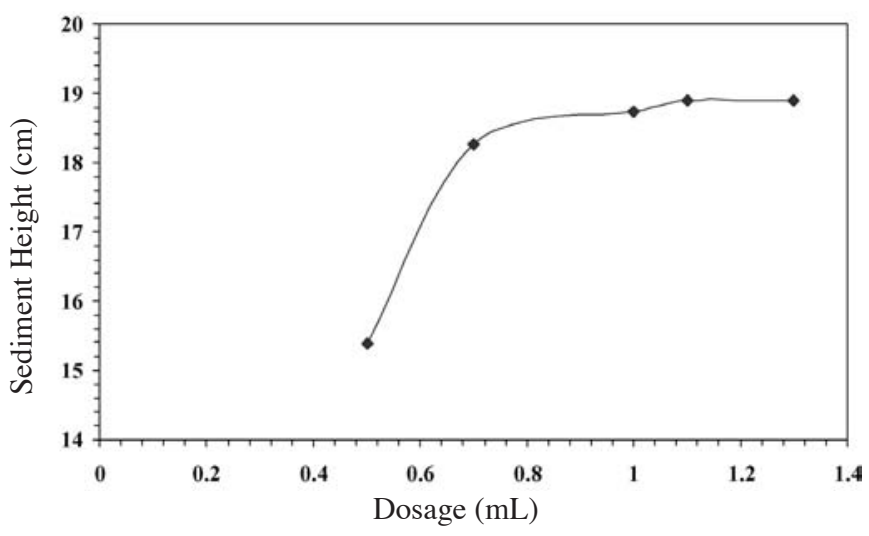

Figure 10: Variation of interface height in aqueous dispersion of alumina nanoparticles for different concentrations of JBR215.

[Figura 10: Variação da altura da interface em dispersões aquosas de alumina nanométrica com diferentes teores de JBR215.]

be attributed to the possible breakdown of the lipids present in the bio-surfactant. Optimum dispersant dose tests are often conducted at low solid loading. However, studies need to be carried out at higher solid loading since it has been shown that a dispersant performance at low solid concentration may not necessarily provide good dispersion at higher solid concentrations. Hence, sedimentation tests with various pulp densities were carried out with optimum dispersant dosage. No instability was caused even at higher solid loading in the presence of Darvan C, as shown in Fig. 12.

The settling kinetics of alumina nanodispersions with different pulp densities in the presence of JBR215 can be inferred from Fig. 13. Higher pulp densities, resulted in higher stabilization. But at higher solid concentration some amount of the solids settled during dispersion. However, in case of smaller particles the stability of dispersion was not affected (no settling observed).

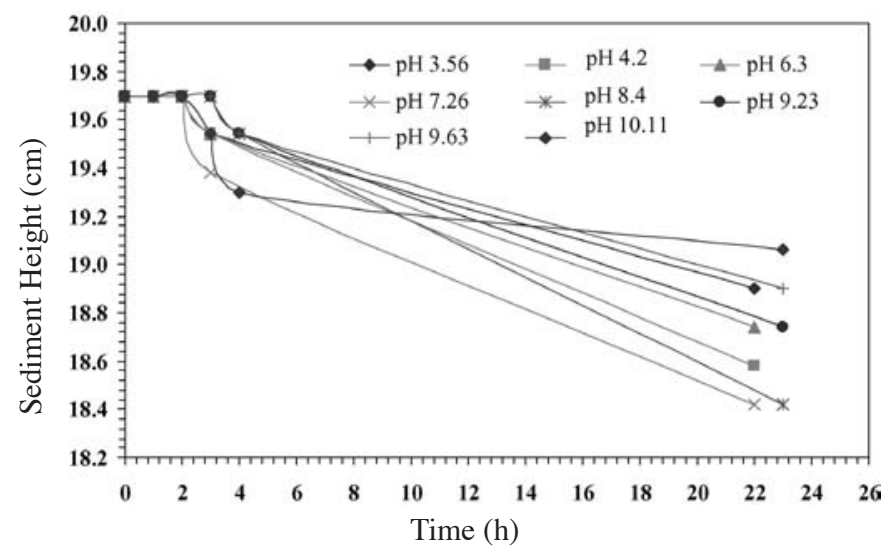

Figure 11: Settling rate of alumina nanoparticles with optimum dosage of JBR215 at different pHs.

[Figura 11: Taxa de sedimentação da alumina nanométrica em diferentes $\mathrm{pHs}$, com teor otimizado de JBR215.]

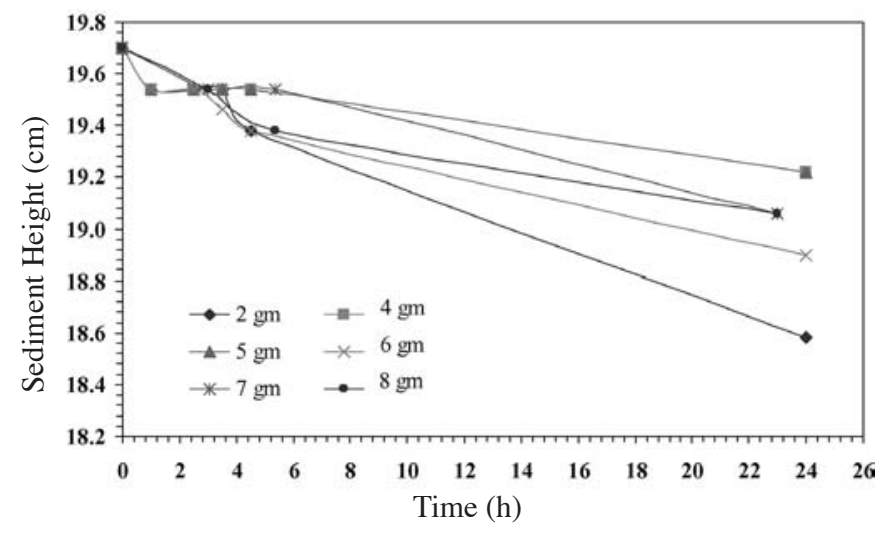

Figure 12: Settling rate for alumina nanodispersions with Darvan C at various pulp densities.

[Figura 12: Taxa de sedimentação para dispersão de alumina nanométrica contendo Darvan C em diversas densidades da pasta.]

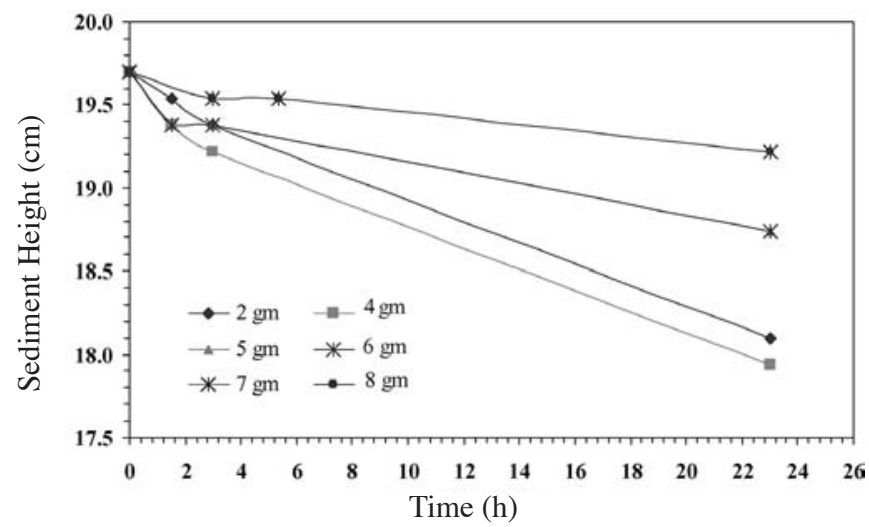

Figure 13: Settling rate for alumina nanodispersion with JBR215 at various pulp densities.

[Figura 13: Taxa de sedimentação para dispersões de alumina nanométrica contendo JBR215 em diversas densidades da pasta.]

\section{CONCLUSIONS}

Alumina nanoparticles dispersed in water in the absence of any dispersant in highly acidic and alkaline media are stable. The IEP of alumina nanopowder used was found to be at pH 9.2. Synthetic polyelectrolyte Darvan C induces higher stabilizing action on aqueous alumina nanodispersion. The dispersion with Darvan $\mathrm{C}$ was stable in a wide range of $\mathrm{pH}$. Optimum dosage of Darvan $\mathrm{C}$ to achieve maximum stability in alumina nanodispersion at IEP was found to be $9.25 \mathrm{mg} / \mathrm{g}$ solids. JBR215, a natural bio-surfactant, also acted as an effective dispersant. Alkaline $\mathrm{pH}$ facilitates stabilizing action in presence of JBR-215 while in acidic $\mathrm{pH}$ range it is not effective. Optimum dosage of JBR-215 to achieve maximum stability in alumina nanodispersion at IEP was found to be $57.75 \mathrm{mg} / \mathrm{g}$ solids. Both Darvan C and JBR-215 were found to be effective dispersants even at higher pulp densities or solid loading. Replacing synthetic polyelectrolytes such as Darvan C with eco-friendly bio-surfactants is advantageous since JBR-215 was also found to be a good dispersant. 


\section{REFERENCES}

[1] R. E. Loehaman, Characterization of Ceramics, $1^{\text {st }}$ Ed., Butterworth-Heinemann Ltd, Reed Pub. Inc., London, UK (1993) p. 43-60.

[2] B. V. D. Eraguin, L. D. Landau, Theory of the stability of the strongly charges lyophobic sols and the adhension of the strongly charged partcles in the solutions of electrolytes, Acta Physicochim. URSS, 14 (1941) 633.

[3] E. Verwey, J. T. G. Overbeek, Theory of the Stability of Lyophobic Colloids, Elsevier, Amsterdam (1948).

[4] R. J. Hunter, Zeta Potential in Colloidal Science, Academic Press, London, UK, 1981.

[5] R. A. Williams, Characterization of Process dispersion, in: R. A. Williams (Ed.), Colloidal and Surface Engineering: Application in the Process Industries, Butterworth-
Heinemann Ltd, London, UK (1992).

[6] C. H. Yeh, M. H. Hon, Dispersion and Stabilization of aqueous TiC suspension, Ceram. Int. 21(1995) 65.

[7] B. P Singh, L. Besra, S. Bhattacharjee, Factorial design of experiments on the effect of surface charges on stability of aqueous colloidal ceramic suspension, Colloids Surf. A: Physicochem. Eng. Aspects 204 (2002) 175

[8] B. P. Singh, S. Bhattacharjee, L. Besra, D. K. Sengupta, Evaluation of dispersibility of aqueous alumina suspension in presence of Darvan C, Ceram. Int. 30 (2004) 1.

[9] B. J. Briscoe, A. U. Khan, P. F. Luckham, Optimising the dispersion on an alumina suspension using commercial polyvalent electrolyte dispersants, J. Eur. Ceram. Soc. 18 (1998) 2141.

[10] L. B. Garrido, E. F. Aglietti, Zircon based ceramics by colloidal processing, Ceram. Int. 27 (2001) 491.

(Rec. 14/09/2004, Rev. 25/02/2005, Ac. 15/04/2005) 